\title{
Analysis of causes, circumstances and consequences of occupational traumatic injuries at the food beverage enterprises
}

\section{Olga Yevtushenko, Alina Siryk, Victoria Zomchak}

\author{
National University of Food Technologies, Kyiv, Ukraine
}

\begin{tabular}{l}
\hline Keywords: \\
Safety \\
Labor \\
Enterprise \\
Traumatism \\
\hline
\end{tabular}

Article history:

Received

20.09.2019

Received in revised form 25.11.2019

Accepted

28.11.2019

\section{Corresponding author:}

Alina Siryk

E-mail: sao30.dn@ gmail.com

\section{DOI:}

$10.24263 / 2310$ 1008-2019-7-2-15

\section{Abstract}

Introduction. The purpose of the study is to determine the causes, consequences and circumstances of occupational injuries at the food beverage enterprises for the period from 2010 to 2018 in Ukraine.

Materials and methods. Applied statistical analysis of data on accidents occurring at food processing enterprises in the production of beverages for the period from 2010 to 2018 was applied during the study; principal component method. The work up of trends in the time series of industrial injuries is based on data from the State Statistics Service of Ukraine.

Results and discussion. In the food industry in the beverage production 221 workers were injured at the food factory, 35 of them died. Of these, $75.6 \%$ were male, $24.4 \%$ were 3 female which is 3 times less than male. It was found that organizational factors lead to $80 \%$ of industrial injuries, the most common organizational reasons were: violation of traffic safety rules $(12.8 \%)$, violations of labor and industrial discipline $(11.2 \%)$, shortcomings in training of safe work practices $(9 \%)$, non-compliance with the requirements of labor safety instructions $(8.2 \%)$ of the total number of injured workers in the food industry in the production of beverages; violation of safety requirements during the operation with the equipment, machines, mechanisms $(7.4 \%)$, failure to fulfill official duties, lack of proper control by managers (5.4\%).

Among the technical reasons, the dominant are the following: design defects, imperfections, insufficient reliability of means of industry, vehicles (5.4\%); poor technical condition of industry facilities, buildings, structures, utilities, territory $(3.6 \%)$; insufficiency of technological process, its non-compliance with safety requirements $(2 \%)$. Psychophysiological causes of trauma are also considered.

Conclusion. Organizational factors lead to $80 \%$ of occupational injuries, of which more than $63 \%$ of all are for workers of 30 to 50 years of age. Basically, violations occur because of poor knowledge of security rules by workers. 


\section{Introduction}

Labour safety have become important cornerstones of social development. Important question is an effectively manage of occupational safety problems.

Occupational injuries and diseases are costly for companies and for society as a whole $[4,28]$.

The continuing high frequency of the food industry occupational accidents calls for new approache for understand the underlying factors $[12,25]$.

A safe, healthy work environment is a crucial factor in a person's quality of life and it is a collective problem. The governments of the EU Member States and the US Government recognize the social and economic benefits of improving health and safety at work [5]. Reliable up-to-date statistical information is vital to setting policy goals and taking appropriate measures and preventative measures [1-2].

It is necessary to implement the selection and concentration by identifying the characteristics of high-risk groups necessary for an effective prevention against and reduction of occupational injuries, including fatal [19].

The purpose of the study is to determine and analyze the causes, consequences and circumstances of industrial injuries at the food beverage enterprises for the period from 2010 to 2018 in Ukraine.

\section{Materials and methods}

\section{Materials}

The work up of trends in the time series of occupational injuries is based on data from the State Statistics Service of Ukraine, taking into account Framework Directive 89/391/ EEC [16] on measures to improve occupational safety and health at work.

Occupational injury statistics are relevant for different countries of the world. Thus, the processing of European statistics on industrial accidents at work is based on the ESAW methodology (ESAW), the US Bureau of Labor Statistics [8] collects data on industrial injuries and diseases; occupational health and safety data are presented in the UK summary statistics [9].

An applied statistical analysis of accidents occurring at the food industry of Ukraine in the production of beverages for the period from 2010 to 2018 was applied during the study.

\section{Methods}

In the analysis of the statistical data of the causes, consequences and circumstances of industrial injuries in food industry in the production of beverages used: method of applied statistical analysis [17] of data on accidents to determine the general trends of injury in the industry; the principal component method [18] for determining the main causes of injury to industry employees.

\section{Results and discussion}

Statistics of accidents at the enterprises of the food industry of Ukraine, show that despite the general tendency of decrease of the number of accidents at the factories in 
Ukraine, in the food industry, the level of industrial injury remains high. The analysis of the dynamics of industrial injury for the period from 2010 to 2018 showed that 221 workers were injured at food enterprises in the production of beverages (Figure 1) [2-3].

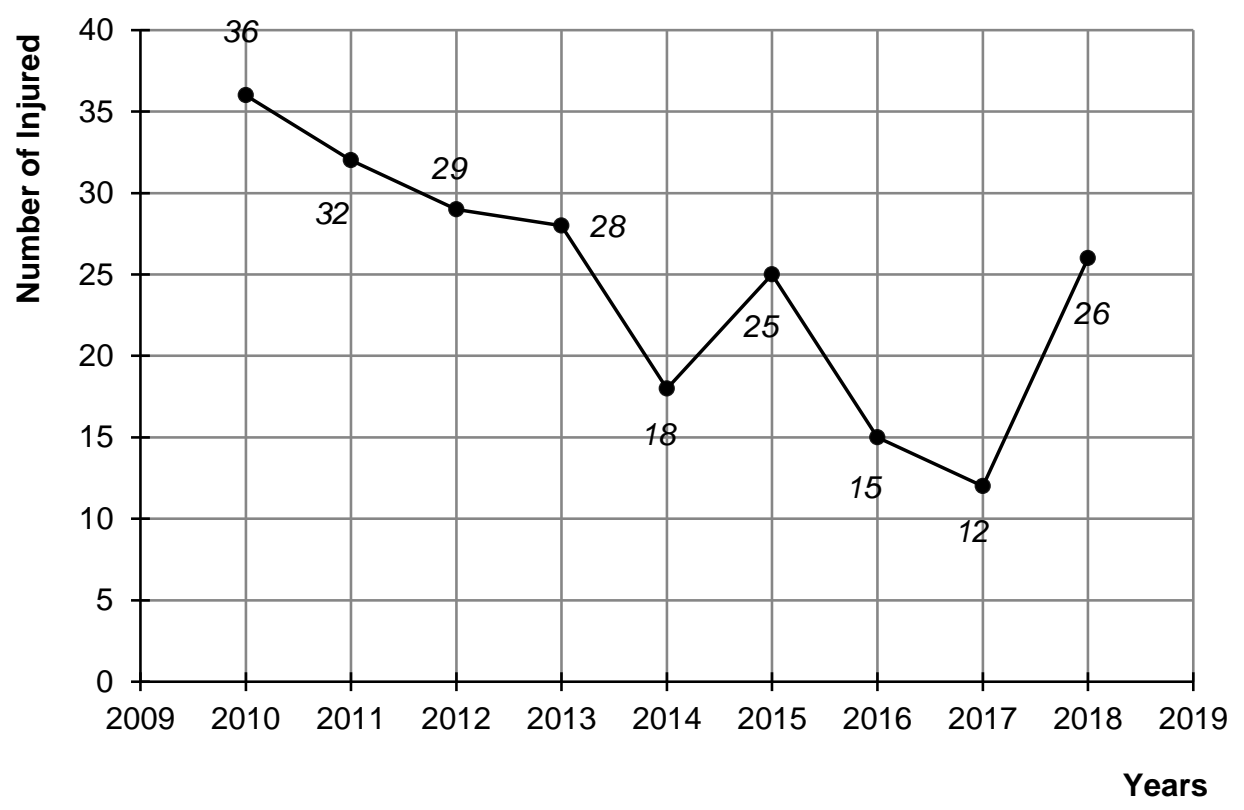

Figure 1. Dynamics of occupational injury at food processing enterprises in beverage
production, 2010-2018

According to the results of the statistical analysis, 221 workers were injured at food processing enterprises in the beverage industry from 2010 to 2018 . Of these, $75.6 \%$ were male and $24.4 \%$ were female, which is 3 times less than the level of injury for men (Figure 2).

According to the analysis of the industrial injury survey for the period 2008-2018, it was found that about $55 \%$ of accidents at the food industry in the production of beverages are related to the operation of the equipment, machines, mechanisms, vehicles.

Analysis of the dynamics of occupational injuries from 2010 to 2018 showed that during that time in the food industry in the beverage production 221 workers were injured at the food factory, 35 of them died. Of these, $75.6 \%$ were male, $24.4 \%$ were female which is 3 times less than male. It was found that organizational factors (Figure 3), lead to $80 \%$ of industrial injuries, the most common organizational reasons were: violation of traffic safety rules $(12.8 \%)$, violations of labor and industrial discipline (11.2\%), shortcomings in training of safe work practices $(9 \%)$, non-compliance with the requirements of labor safety instructions $(8.2 \%)$ of the total number of injured workers in the food industry in the production of beverages; violation of safety requirements during the operation with the equipment, machines, mechanisms $(7.4 \%)$, failure to fulfill official duties, lack of proper control by managers $(5.4 \%)$. 


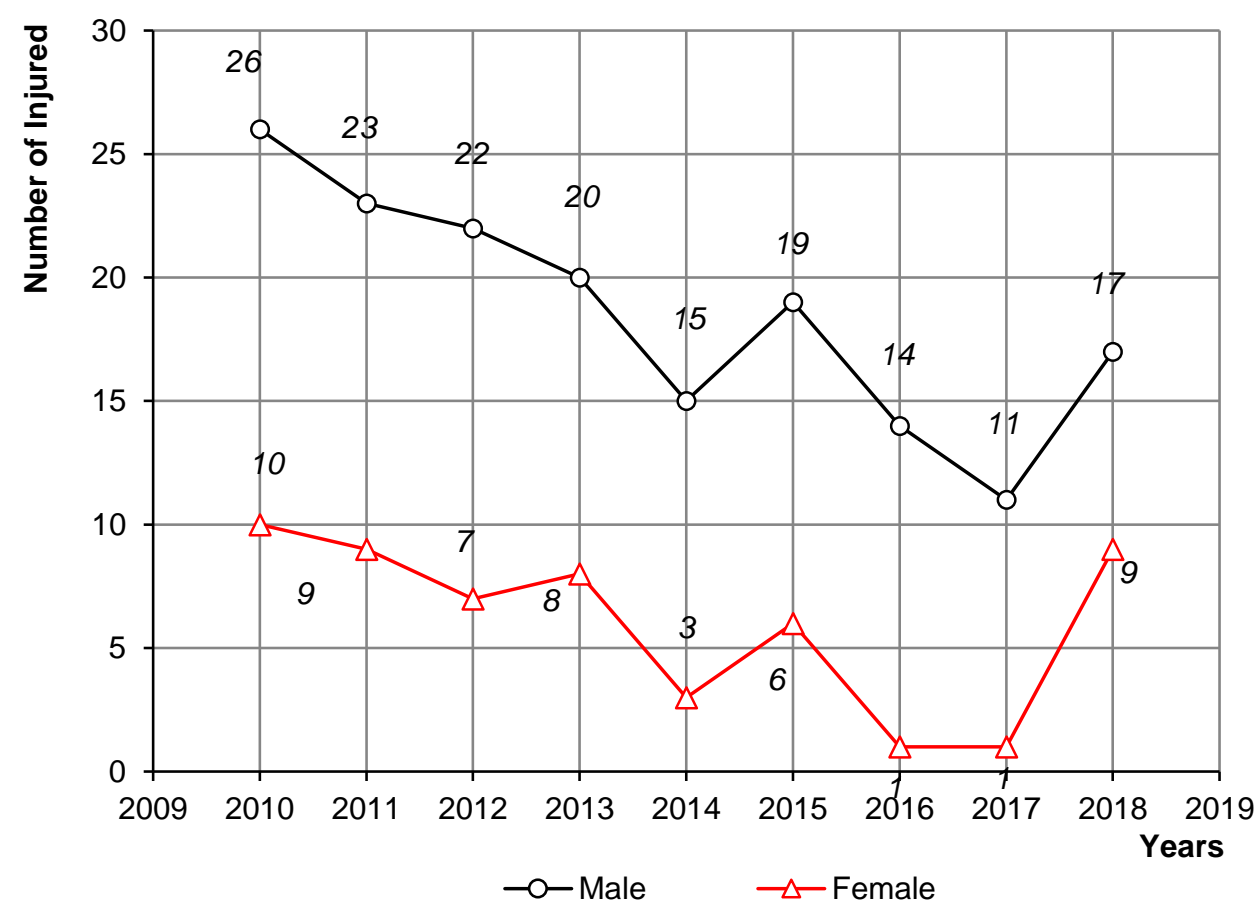

Figure 2. Dynamics of the numbers of injured male and female workers in the food industry in the production of beverages, $2010-2018$

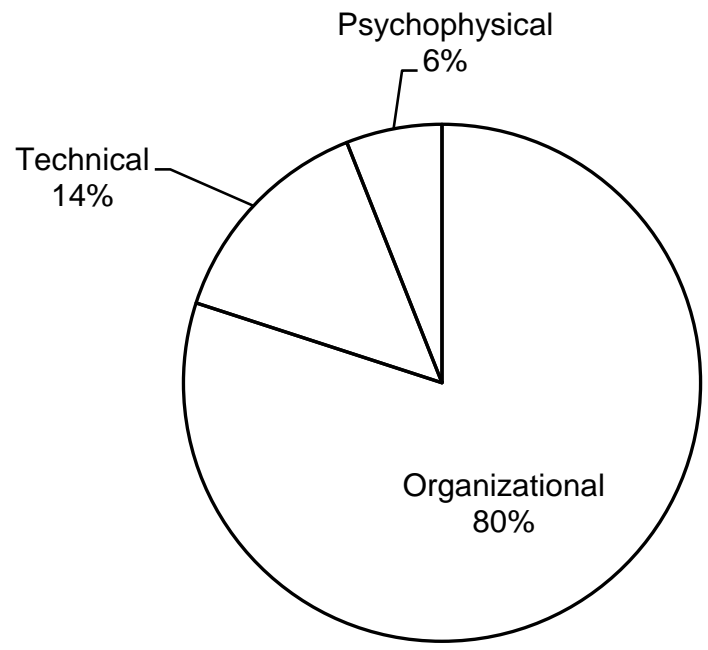

Figure 3. Dividion of the number of victims of occupational injuries by main causes at the food industry in the production of beverages, 2010 - 2018 
World statistics confirmed that men and women faced different levels of risks in distinct work environments [27].

According to results, male workers have comprised a large proportion of occupational fatalities. A common explanation for men has been that men are overrepresented in more physically hazardous occupations. Yet another potential explanation is that prescribed gender roles and norms contribute to higher rates of male worker fatalities compared with female workers [23].

It was payed attention, that men may be at increased risk for occupational fatalities when compared to women in the same occupations, and advocate for investigating the role of gender for future research on injury and fatality discrepancies between male and female workers [23].

Among the technical reasons, the dominant are the following: design defects, imperfections, insufficient reliability of means of industry, vehicles $(5.4 \%)$; poor technical condition of industry facilities, buildings, structures, utilities, territory (3.6\%); insufficiency of technological process, its non-compliance with safety requirements $(2 \%)$.

The most common psychophysiological reasons were: alcohol-related injuries $(3.8 \%)$ and unlawful acts of others (1\%), personal negligence of the victim $(1 \%)$ of the total number of injured persons in the food industry.

The analysis of statistics shows that for the types of events that lead to accidents at the food industry, the major ones are the following: the car accidents both on public roads and on the territory of the enterprise $(24.6 \%)$; the action of objects and parts that move, fly, rotate $(12.4 \%)$; fall of the victim (9.2\%), including from the height (4\%); and falls, collapses, falls of objects, materials, rocks, soil, etc. $(4.8 \%)$.

The influence of various factors (total work experience, specialty experience, age of the victims) on the magnitude of the frequency of injury was analyzed.

Of particular concern is the fact that more than $63 \%$ of all accidents occur to workers of 30 to 50 years of age. Most workers of this age have managed to change several jobs at different factories, over-confident and overestimating their own capabilities, which diminish attention and lead to violation of safety rules during the technological process, which eventually creats an emergency situation.

Some scientist pay attention that mechanical factors such as heavy lifting, psychosocial factors such as low control over work pace, and organizational factors such as safety climate are all associated with increased injury risk for young workers. Researchers and practitioners have to account for this complexity in the education, training and organization of work, and workplace health and safety culture [24].

A large part of the injuries happens to the workers with more than 20 years of experience and those with 1 to 5 years of professional experience. Both categories are characterized by an extremely negative factor with hyperbolization of one's own experience in dealing with standard situations [5]. Particular attention should be paid to these facts during the first meeting and repeated on the job briefings. In addition, it is necessary to improve the quality of the briefings themselves, to strengthen the control over the work of employees with little professional experience.

The fatal accidents have been analyzed separately. According to the results of the statistical analysis, 35 employees died at the food processing enterprises in the beverage production from 2010 to 2018.

The analysis showed that more than $30 \%$ of the employees who died at the food processing industry in the beverage production don't go through training of the profession during which the accident occurred. In addition, no introductory instruction was conducted to the $12 \%$ of the victims. Knowledge testing for high-risk works has not been conducted for 
more than half of the dead. These facts testify to the shortcomings in the professional training of industry workers and poor, formal training at food processing enterprises. According to the study, the victim violated labor law in $48 \%$ of accidents with fatal consequences, while the other in almost $52 \%$. In more than half of the accidents, the ones who violated the rules were at different levels in the labor protection legislation. Therefore, there is a need to increase the accountability of managers at all levels in industry to prevent them from violating labor safety laws that lead to accidents.

Summarizing the above, it can be said that organizational and qualification factors in food processing companies lead to $80 \%$ of occupational injuries. Basically, these violations occur because of poor knowledge of security rules by workers. This problem is caused by the insufficiency of training, the formalism in the training and in the instruction of workers at the workplace, the little knowledge of labor protection requirements by workers.

For this reason, in order to prevent occupational injuries and increase the level of safety at food processing enterprises in the of beverage production to employers, it is necessary, first of all, to strengthen the control over the compliance with traffic rules by employees whose work is related to the transportation of food products; improve the quality of training and development of safety instructions; improve the effectiveness of training and validation of occupational safety knowledge of workers, including those employed in high-risk jobs; provide monitoring of production equipment, control systems, production process management, alarms and communications; to monitor compliance with the requirements of legislative and regulatory acts on labor protection by both employees and managers of structural units. The foresight research is considered to be an obligatory tool for successful scientific, technological and innovation policy $[6,7]$.

Despite the positive changes, Ukraine is still ahead of the developed countries in terms of the number of injured persons in production-10]. Among the main reasons are the general socio-economic situation in the country, lagging behind world trends and developments in the field of labor protection. The level of occupational injuries of the countries of Western and Eastern Europe of Japan, the USA, the United Kingdom is closely connected with more advanced technological processes, the equipment, and also the organization of production.

Pay attention on the conclusion [20] that personal perceptions of occupational risk are inaccurate, perhaps because workers are usually fully informed about work-related risks only after wage negotiations are concluded and a contract is signed.

The emphasis on the innovative dimensions of prevention activities, the intensive use of quality management tools, and the empowerment of workers are all factors contributing to reduce the number of injuries. By contrast, the implementation of flexible manufacturing processes is associated to higher accident rates [26].

Many industries are concerned about adopting an appropriate shift schedule for their workers. Interesting result show the research of impact on a group of production workers of changing from an 8-h to a 12-hr rotating schedule [29]. It was indicated a strong preference of the workers for the 12-h schedule with positive influences on the workers' subjective feeling toward health and social family life. That study also indicated that there was no significant change in the occupational injury rate [29].

Therefore, for the constant control and monitoring of the state of occupational safety, it is necessary to introduce modern information and analytical systems of occupational safety management, which should be organized taking into account the clear interaction of the head of the service (department) of occupational safety with the managers of all structural divisions of the food enterprise, for adequate and permanent management of taking into account all factors affecting the state of occupational safety and providing managers of structural units with an optimal set of measures to ensure safety at work [11-15]. 


\section{Conclusion}

The level of occupational injury remains high, for the period 2010-2018, 221 workers were injured, 35 of them died. The study found that organizational factors lead to $80 \%$ of occupational injury. More than $63 \%$ of all accidents happened to employees of 30 to 50 years of age. Most of the injuries happened to the workers with more than 20 years of experience and those with 1 to 5 years of professional experience. In more than half of the accidents, the ones who violated the rules were at different levels in the labor protection legislation. Particular attention should be paid to these facts during the first meeting and repeated on the job briefings. In addition, it is necessary to improve the quality of the briefings themselves, to strengthen the control over the work of employees with little professional experience. It is necessary to increase the responsibility of managers of all levels in industry in order to prevent them from violating the labor protection laws that lead to accidents.

The results of the studies can serve as a theoretical basis for the construction of a mathematical model of optimal planning of occupational safety at food industry in the production of beverages in order to significantly reduce the level of occupational injury.

Safety professionals and researchers can use the study findings to inform future intervention efforts in this industry [21].

The results of the study can also be of assistance for professionals involved in planning, implementing and controlling the national policy and/or regional policies on safety and health at work [22].

\section{References}

1. Christina Mischke, Jos H Verbeek, Jenny Job, Thais C. Morata, Anne AlvesaloKuusi, Kaisa Neuvonen, Simon Clarke, Robert Pedlow (2013), Occupational safety and health enforcement tools for preventing occupational diseases and injuries, The Cochrane Database of Systematic Reviews.

2. Leigh J.P. (2011), Economic Burden of Occupational Injury and Illness in the United States, Milbank Quarterly, 89(4), pp.728-772.

3. Hans Pasman, William Rogers, (2014), How can we use the information provided by process safety performance indicators? Possibilities and limitations, Journal of Loss Prevention in the Process Industries, 30, pp. 197-206

4. Yevtushenko O., Siryk A., Porodko P., Kovbych V. (2017), Doslidzhennia vyrobnychoho travmatyzmu na pidpryiemstvakh kharchovoi promyslovosti pry vyrobnytstvi napoiv, Kharchova promyslovist, 22, pp.164-168.

5. Julie Laurent, Nik Chmielb, Isabelle Hansez (2018), Jobs and safety: A social exchange perspective in explaining safety citizenship behaviors and safety violations, Safety Science, 110(A), pp. 291-29

6. OECD (2016), Technology and Innovation Outlook 2016, OECD Publishing, Paris.

7. OECD (2017), Technology and Industry Scoreboard 2017: The digital transformation, OECD Publishing, Paris.

8. Industry Injury and Illness Data. U.S. Bureau of Labor Statistics, Available at: http://www.bls.gov/iif/oshsum.htm

9. Health and safety at work. Summary statistics for Great Britain 2019, Available at: https://www.hse.gov.uk/statistics/overall/hssh1819.pdf 
10. Facts on Safe Work ILO Statistics, Available at: https://www.ilo.org/legacy/english/protection/safework/worldday/facts_eng.pdf, Information https://ec.europa.eu/eurostat/

11. Yevtushenko O. (2018), Intelektualizatsiia informatsiino-analitychnoi systemy upravlinnia okhoronoiu pratsi na kharchovomu pidpryiemstvi, Naukovi pratsi Natsionalnoho universytetu kharchovykh tekhnolohii, 24 (3), pp. 100-112.

12. Yevtushenko O. (2015), Kompleks zasobiv avtomatyzatsii upravlinnia okhoronoiu pratsi dlia pidpryiemstv kharchovoi promyslovosti, Naukovi pratsi Natsionalnoho universytetu kharchovykh tekhnolohii, 21(2), pp. 122-131.

13. Elmontsri M. (2014), Review of the Strengths and Weaknesses of Risk Matrices. Journal of Risk Analysis and Crisis Response, 4(1), pp. 49-57

14. Laktionov S., Sierikov Ya. (2015), Vyrobnychyi travmatyzm i profesiina zakhvoriuvanist yak problema suchasnosti: aspekty, prychyny, shliakhy zapobihannia. Mizhnarodna konferentsiia: Bezpeka liudyny u suchasnykh umovakh. NTU "KhPI", pp. 219-224.

15. Kruzhilko O., Bogdanova O. (2016), Method of human factor minimization in expert judgement for occupational risk assessment and decision making, Ukrainian Journal of Food Science, 4(1), pp. 238-250.

16. The OSH Framework Directive, Available at: https://osha.europa.eu/en/legislation/directives/the-osh-framework-directive/theosh-framework-directive-introduction

17. Irving W. Burr (2014), Applied Statistical Methods. Operations research and industrial engineering, Elsevier.

18. Alboukadel Kassambara (2017), Multivariate Analysis II: Practical Guide to Principal Component Methods in R: PCA, M(CA), FAMD, MFA, HCPC, factoextra, STHDA.

19. Kwan Hyung Yi (2018), The High-risk Groups According to the Trends and Characteristics of Fatal Occupational Injuries in Korean Workers Aged 50 Years and Above, Safety and Health at Work, 9(2), pp. 184-191.

20. Paweł Strawiński, Dorota Celińska-Kopczyńska (2019), Occupational injury risk wage premium, Safety Science, 118, pp. 337-344.

21. Laura N. Syron, Devin L. Lucas, Viktor E. Bovbjerg, Samantha Case, Laurel Kincl (2018), Occupational traumatic injuries among offshore seafood processors in Alaska, 2010-2015, Journal of Safety Research, 66, pp. 169-178.

22. Miran Pavlič, Borut Likar, Alenka Pavlič, Mirko Markič (2011), Managing occupational injuries records in Slovenia from 1948 to 2008, Safety Science, 49(6), pp. 834-842.

23. Timothy J. Bauerle, Alyssa K. McGonagle, Vicki J. Magley (2016), Mere overrepresentation? Using cross-occupational injury and job analysis data to explain men's risk for workplace fatalities, Safety Science, 83, pp. 102-113.

24. Therese N. Hanvold, Pete Kines, Mikko Nykänen, Sara Thomée, Kaj B. Veiersted (2019), Occupational Safety and Health Among Young Workers in the Nordic Countries: A Systematic Literature Review, Safety and Health at Work, 10(1), pp. 3-20.

25. Christina Stave, Marianne Törner (2007), Exploring the organisational preconditions for occupational accidents in food industry: A qualitative approach, Safety Science, 45(3), pp. 355-371 
26. Pablo Arocena, Imanol Núñez, Mikel Villanueva (2008), The impact of prevention measures and organisational factors on occupational injuries, Safety Science, 46(9), November 2008, pp. 1369-1384.

27. Fernanda Cruz Rios, Wai K. Chong, David Grau (2017), The need for detailed gender-specific occupational safety analysis, Journal of Safety Research, 62, pp. 53-62.

28. Martin Lebeau, Patrice Duguay, Alexandre Boucher (2014), Costs of occupational injuries and diseases in Québec, Journal of Safety Research, 50, pp. 89-98.

29. Mark D. Johnson, Joseph Sharit (2001), Impact of a change from an 8-h to a 12-h shift schedule on workers and occupational injury rates, International Journal of Industrial Ergonomics, 27(5), pp. 303-319. 